\section{In Memoriam: David B. Estell}

\author{
Roger J. R. Levesque ${ }^{1}$
}

Published online: 3 June 2019

(C) Springer Science+Business Media, LLC, part of Springer Nature 2019

It is with profound regret that I announce the loss of one of our journal's most dedicated editorial board members, David Bernhardt Estell. He passed away on Tuesday, February 19, 2019 at the age of 45, following a very brief bout with an aggressive form of cancer.

David was born on June 28, 1973, in San Diego, California, and spent much of his childhood in Ridgecrest, California, where he formed a number of lifelong friendships. He received a B.S. in Psychology from the University of California at Davis in 1995, and a Ph.D. in Developmental Psychology from the University of North Carolina at Chapel Hill in 2001. After a postdoctoral year at UNC, he began teaching at Indiana University Bloomington as Assistant Professor in the School of Education in 2002. He was promoted to Associate Professor and granted tenure in 2008, and served as the head of both the Human Development and Education Psychology programs.

David and I taught at the same university. His office was across campus, but our paths often crossed. He served on the editorial board for over a decade, and he also served on Adolescent Research Review, which is working on its fifth volume. He was responsible for spearheading a highly successful special issue on rural youth's development, a 2011 special issue that led to much research focusing on rural youth. His reviews were always detailed, helpful and thoughtful. They also were always on time, as he was always eager to serve and do so responsibly. He never declined an invitation to help. He had accepted to review a manuscript a few days before he passed away.

In addition to having reviewed many dozens of manuscripts for the journals I edit, David served as a key contact person who readily shared his statistical and methodological expertise to help me make ultimate editorial decisions. He also was a constant source of potential reviewers, as he had

Roger J. R. Levesque

rlevesqu@indiana.edu

1 Indiana University, 302 Sycamore Hall, Bloomington, IN, USA a very wide and deep social network of colleagues who shared his eagerness to help others develop and publish their work. For me, he also was a source of excellent students who could serve as research assistants, as he had many students interested in developmental dimensions of adolescence.

His ability to think through issues and provide guidance was well known among those who knew him. That talent was often sought. He not surprisingly ended up in a variety of service and administrative roles in the school of education and broader university. He notably served on the executive council of the Bloomington Faculty Council. We served on that council together and shared a lot of laughs. He was as clever as it gets. People liked to have him around!

Professionally, David was perhaps best known for his research relating to social development, with an emphasis on peer relations and peer dynamics. Yet, his expertise and impact went much beyond that. For example, the articles he published in this journal and helped to develop actually focused on rural youth (see Estell et al. 2007). That research eventually not only developed the study of rural youth but also reshaped how we understand other youth, such as those who have been victimized (see Dawes et al. 2017; Dawes and Malmut 2018), are transitioning from one type of school to another (Benner et al. 2017), or have disabilities (Maxey and Beckert 2017). In addition to that line of research, his research record included important studies that focused on understanding the sources of charitable giving in youth and the effects of parental loss. A look at his work reveals that he was concerned with how people connected with one another. That work also reveals how he also connected so well with outhers: he worked with many colleagues and was committed to the success of his students, several of whom have gone on to become tenured professors at public and private teaching and research universities.

David is survived by his daughters, Eleanor, age 9, and Lillian (Lily), age 3, of Bloomington, Indiana; his former wife, Carolyn Munk Estell, of Bloomington; his father, 
Robert Estell, of Bloomington; and his brother, Michael Estell, of Brookline, Massachusetts. He is also survived by many colleagues like me who miss him dearly.

\section{Compliance with Ethical Standards}

Conflict of Interest The author declares that he has no conflict of interest.

Publisher's note: Springer Nature remains neutral with regard to jurisdictional claims in published maps and institutional affiliations.

\section{References}

Benner, A.D., Boyle, A.E., \& Bakhtiari, F. (2017). Understanding students' transition to high school: demographic variation and the role of supportive relationships. Journal of Youth and Adolescence, 46, 2129-2142.
Dawes, M., Chen, C.-C., Farmer, T.W., \& Hamm, J.V. (2017). Selfand peer-identified victims in late childhood: differences in perceptions of the school ecology. Journal of Youth and Adolescence, 46(11), 2273-2288.

Dawes, M., \& Malmut, S., (2018). No one is safe: victimization experiences of high-status youth., Adolescent Research Review, https://doi.org/10.1007/s40894-018-0103-6.

Estell, D.B., Farmer, T.W., Irvin, M.J., Thompson, J.H., Huthins, B. C., \& McDonough, E.M. (2007). Patterns of middle school adjustment and ninth grade adaptation of rural African American Youth: Grades and substance use. Journal of Youth and Adolescence, 36, 477-487.

Maxey, M., \& Beckert, T.E. (2017). Adolescents with disabilities. Adolescent Research Review, 2, 59-75.

Roger J. R. Levesque is Professor of Criminal Justice and (Affiliate) Law, Indiana University. He serves as Editor-in-Chief of the Journal of Youth and Adolescence and the Adolescent Research Review. He also is editor of the Advancing Responsible Adolescent Development book series. 